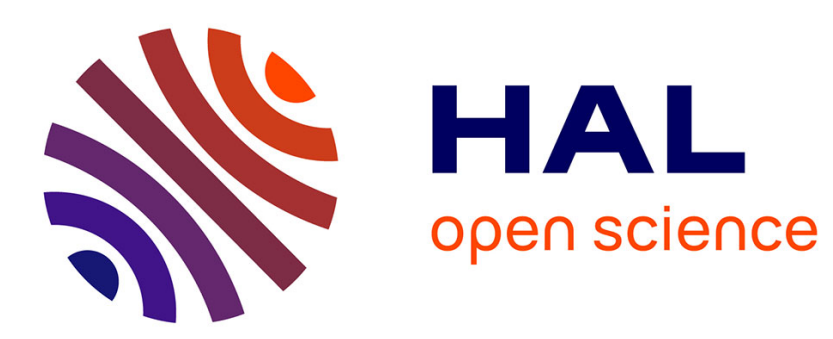

\title{
A furnace for diffraction studies using synchrotron X-ray radiation
}

\author{
B. Buras, B. Lebech, W. Kofoed
}

\section{To cite this version:}

B. Buras, B. Lebech, W. Kofoed. A furnace for diffraction studies using synchrotron X-ray radiation. Revue de Physique Appliquée, 1984, 19 (9), pp.743-745. 10.1051/rphysap:01984001909074300 . jpa00245250

\section{HAL Id: jpa-00245250 https://hal.science/jpa-00245250}

Submitted on 1 Jan 1984

HAL is a multi-disciplinary open access archive for the deposit and dissemination of scientific research documents, whether they are published or not. The documents may come from teaching and research institutions in France or abroad, or from public or private research centers.
L'archive ouverte pluridisciplinaire HAL, est destinée au dépôt et à la diffusion de documents scientifiques de niveau recherche, publiés ou non, émanant des établissements d'enseignement et de recherche français ou étrangers, des laboratoires publics ou privés. 


\title{
A furnace for diffraction studies using synchrotron $\mathbf{X}$-ray radiation
}

\author{
B. Buras $(*)$, B. Lebech and W. Kofoed \\ Physics Department, Ris $\phi$ National Laboratory, DK-4000 Roskilde, Denmark
}

\begin{abstract}
Résumé. - On décrit un four pour expériences de diffraction des rayons $\mathrm{X}$ utilisant le rayonnement synchrotron. Ce four peut être utilisé entre la température ambiante et $1800^{\circ} \mathrm{C}$ avec une stabilité meilleure que $5^{\circ} \mathrm{C}$ à des températures supérieures à $300^{\circ} \mathrm{C}$. Des fenêtres en Kapton permettent un accès de presque $360^{\circ} \mathrm{C}$ aux rayons $\mathrm{X}$ dans un plan horizontal. Des expériences à longueur d'onde fixe ou angle de diffusion fixe sont ainsi possibles. Divers détails de construction du four sont explicités.
\end{abstract}

\begin{abstract}
A furnace for diffraction studies using synchrotron X-ray radiation is described. The furnace can be operated between ambient temperature and $1800^{\circ} \mathrm{C}$ with a temperature stability better than $5^{\circ} \mathrm{C}$ for temperatures above $300^{\circ} \mathrm{C}$. Kapton windows allow almost $360^{\circ}$ access for the X-ray beam in the horizontal scattering plane and the furnace may be used in both conventional monochromatic beam angle-dispersive and white-beam energydispersive diffraction experiments. Details of the furnace windows, heating element, thermometry and sample mount are given.
\end{abstract}

\section{Introduction.}

X-ray diffraction studies at low or elevated temperatures often prove difficult because the sample has to be contained in a controlled atmosphere (vacuum or inert gas) which means that the $\mathrm{X}$-ray beam has to pass through windows that may absorb most of the $\mathrm{X}$-ray beam. Use of synchrotron $\mathrm{X}$-ray radiation to some extent eliminates this problem because the synchrotron X-ray sources are considerably more intense than conventional $X$-ray sources. The furnace to be described below is a modified version of a furnace which has previously been used for neutron diffraction experiments. The X-ray furnace has been used for diffraction experiments at Desy, Hasylab, Hamburg, F.R.G. during the last two years either for single crystal diffraction experiments in conjunction with a conventional monochromatic beam angle-dispersive diffractometer or for powder work using the white beam energy-dispersive diffractometer. The two diffraction techniques are schematically illustrated in figure 1 . In the angle-dispersive method a monochromatic beam of wavelength $\lambda_{0}$ is selected from the white synchrotron X-ray beam by means of a crystal mono-

(*) Also at Physics Laboratory II, University of Copenhagen, Universitetsparken 5, DK-2100 Copenhagen, Denmark. Present address : European Synchrotron Radiation Project, c/o CERN, CH-1211 Geneve 23, Switzerland.

\section{DIFFRACTION TECHNIQUES}

Angle-dispersive

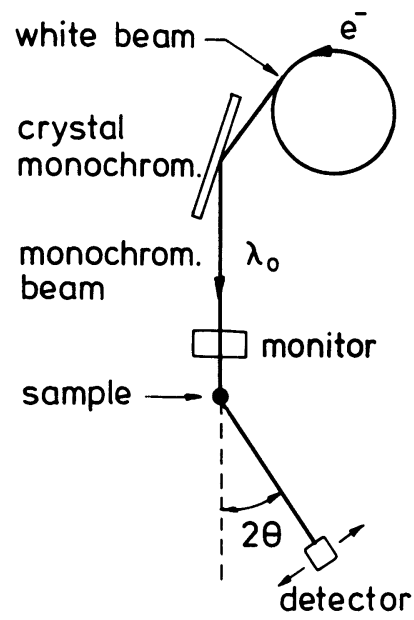

$\lambda_{0}=$ const .

$\frac{2 \theta=\text { variable }}{2 d_{H K L} \cdot \sin \theta_{H K L}=\lambda_{\circ}}$
Energy-dispersive



$\lambda=$ variable

$\frac{2 \theta_{0}}{2 d_{H K L}}=$ const.
Fig. 1. - Schematic illustration of diffraction techniques. The angle-dispersive technique is used for both single crystal and powder diffraction. The energy-dispersive technique is best suited for diffraction studies of powders. 
chromator and the intensity of the diffracted beam is measured as a function of the scattering angle $2 \theta$. In the energy-dispersive method the scattering angle $2 \theta_{0}$ is fixed and the white synchrotron X-ray beam is impinging on the sample. The wavelength (photon energy) composition of the diffracted beam is analysed by means of a solid state detector (SSD).

\section{Technical description of the furnace.}

The assembled X-ray furnace is shown in figure 2 . The double walled outer housing in which the cooling water flows $(0.5-1 \mathrm{1} / \mathrm{m})$ is disconnected from the top flange of the furnace at the vacuum joint G. All connections into the furnace such as power supply cables, vacuum exhaust, cooling water connections, and sample mounting are done through the top flange.



Fig. 2. - Assembled X-ray furnace. A) Kapton window ( $\sim 0.05 \mathrm{~mm}$ thick). B) Top-loaded sample rod with thermocouples. C) Moveable shield for protection of the Kapton window. D) Power supply cables. E) In- and out-lets for the cooling water $(0.5-1 \mathrm{l} / \mathrm{m})$. F) Double-walled outer housing. G) Vacuum joint.

The sample and thermocouples are mounted on a toploaded sample rod which means that the sample can be changed without disassembling the furnace at the top flange. Figure 3 shows a photograph of the furnace when disassembled at the top flange. Below we describe in some detail the most important points of the furnace.

a) Windows : in order to minimize the absorption of the X-ray beam when passing through the furnace we use a $0.05 \mathrm{~mm}$ thick Kapton window (Fig. 2-A) which allows almost $360^{\circ}$ access for the X-ray beam in the horizontal plane. However, when the furnace is used in conjunction with the energy-dispersive technique, the full white synchrotron $\mathrm{X}$-ray spectrum has to pass through the furnace, and this beam is so intense that the Kapton window may burn. Therefore, in connection with energy dispersive diffraction we use a special outer housing, where parts of the Kapton window (entrance and exit of the direct beam) have been replaced by aluminium windows.

b) Heating element : the heating element (Fig. 3-C) is made of a graphite cylinder (inner diameter $20 \mathrm{~mm}$. wall thickness at beam height $0.3 \mathrm{~mm}$ ) in which a $3 \mathrm{~mm}$ vertical slit has been cut. The heating element is mounted so that the direct beam passes through the slit, and hence only the scattered beam has to pass through graphite. This means that the background

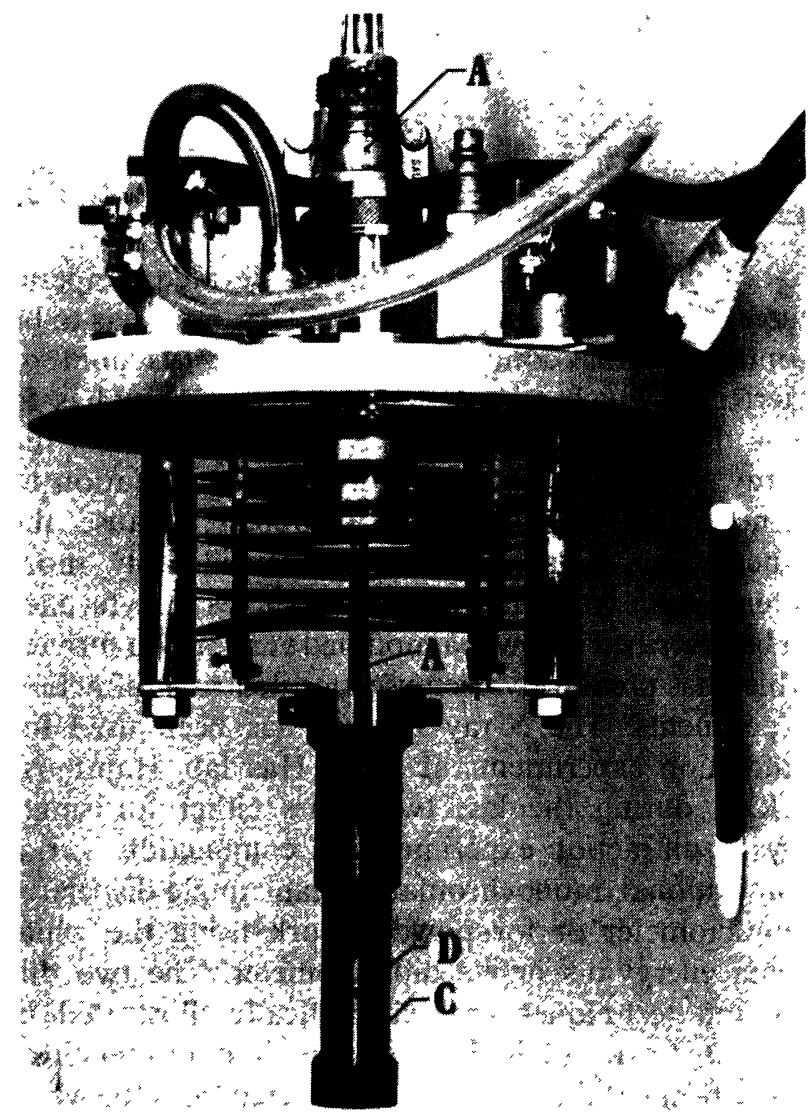

Fig. 3. - X-ray furnace without the outer housing and some of the radiation shields. A) Top-loaded sample rod with thermocouples. B) Molybdenum radiation shields. Cylindrical radiation shields surround the heating element when the furnace is assembled. C) Low resistance graphite heating element. D) Sample holder. 
scattering from the heating element is limited as much as possible. The resistance of the heating element is about $1 \Omega$.

c) Radiation shields : in order to limit the heat loss we use $0.1 \mathrm{~mm}$ thick molybdenum radiation shields. Six circular plates are mounted at the top (Fig. 3-B) and bottom of the furnace, and further six cylindrical radiation shields surround the heating element. Nearly $360^{\circ}$ windows have been cut in the cylindrical shields at beam height in order to eliminate the absorption and scattering in the radiation shields. For work above $1100^{\circ} \mathrm{C}$ it is necessary to use additional radiation shields of graphoil, and this increases the background somewhat.

d) Sample rods : the samples are mounted at the end of the sample rod. Thermocouples are led through the sample rod and mounted so that they are in as close contact as possible with the sample. Two types of sample rods are presently available; one for low (up to $1100^{\circ} \mathrm{C}$ ) and one for high temperatures (1 100$\left.1800^{\circ} \mathrm{C}\right)$. In the first case, we use chromel-alumel thermocouples and a sample rod of a thin-walled stainless steel tube. The sample is mounted in a sample holder of steel which is in direct contact with the thermocouples. For work below $300^{\circ} \mathrm{C}$ a special heater has been wound around the sample holder for fine adjustment of the sample temperature. For high temperature work, we use tungsten-rhenium thermocouples which are led to the sample holder through channels in the sample rod made of sintered $\mathrm{Al}_{2} \mathrm{O}_{3}$. The sample holder is made of molybdenum foil which is glued to the thermocouples by high temperature cement.

e) Performance : when combined with an appropriate temperature controller, the furnace may be operated between ambient temperature and $1800{ }^{\circ} \mathrm{C}$ with a temperature stability better than $5^{\circ} \mathrm{C}$ for temperatures above $300^{\circ} \mathrm{C}$. For a flow rate of $0.5-1 \mathrm{l} / \mathrm{m}$ of the cooling water, the power consumption increases with temperature from $\sim 30 \mathrm{~W} / 100^{\circ} \mathrm{C}$ for $T<$ $1000^{\circ} \mathrm{C}, \sim 130 \mathrm{~W} / 100^{\circ} \mathrm{C}$ for $1000^{\circ} \mathrm{C}<T<$ $1500^{\circ} \mathrm{C}$ to $220 \mathrm{~W} / 100^{\circ} \mathrm{C}$ for $1500^{\circ} \mathrm{C}<T<1800^{\circ} \mathrm{C}$.

\section{Examples of experiments.}

The furnace has been used for instance in a study of the crystallization process in the soft magnetic metallic glasses $\mathrm{Fe}_{x} \mathrm{Si}_{90-x} \mathrm{~B}_{10}$ [1]. The experiments were performed using synchrotron $\mathrm{X}$-ray radiation and the energy-dispersive diffractometer at Doris, Hasylab, Desy, Hamburg, F.R.G. The white X-rays from Doris range up to $60 \mathrm{keV}$, which for the scattering angle $2 \theta=21^{\circ}$ corresponds to a maximum scattering vector of $11 \AA^{-1}$. The technique enables the recording of a full diffraction pattern of reasonable statistics in 3-5 minutes. The crystallization was followed either by heating the sample stepwise from $20^{\circ} \mathrm{C}$ to $1000^{\circ} \mathrm{C}$ or by repeatedly recording the diffraction patterns obtained from a sample while annealing at a fixed temperature close to the crystallization temperature or above. A series of isothermal diffraction patterns were used to study the kinetics of the crystallization of $\mathrm{Fe}_{x} \mathrm{Si}_{90-x} \mathrm{~B}_{10}(69<x<83)$. The crystallization of $\alpha$-Fe in $\mathrm{Fe}_{83} \mathrm{Si}_{7} \mathrm{~B}_{10}$ at $350^{\circ} \mathrm{C}$ was found to be nearly complete after $\sim 700$ minutes and the kinetics may be described by the phenomenological Avrami equation, yielding $\eta=1.3$.

The furnace is presently being used in a conventional monochromatic beam study of the $\beta-\varepsilon$ structural phase transition of $\mathrm{V}_{2} \mathrm{H}$ at $170{ }^{\circ} \mathrm{C}$ [2], and has previously been used in a search for a structural phase transition in $\mathrm{CeO}_{2}$ [3]. In the latter study, no phase transition was observed up to $1800^{\circ} \mathrm{C}$.

\section{References}

[1] Minor, W., Schönfeld, B., Lebech, B., Buras, B. and DMOWSKI, W., Crystallization in metallic glasses. In : Jahresbericht 1983 für Deutsches Synchrotronstrahlungslabor, Hasylab, Desy, Hamburg, F.R.G. (January 1984).

[2] SCHÖNFELD, B. and KJÆR, K., private communication (1984).

[3] Buras, B. and Cox, D., private communication (1980). 